\title{
OBSERVATIONS ON THE SUBGENUS RHACHIOCREMA (HYMENOPTERA: FORMICID尼) WITH THE DESCRIPTION OF A NEW SPECIES FROM BORNEO
}

\author{
By Wm. S. CReighton \\ Dept. of Biology, City College, C.C.N.Y.
}

Of the several subgenera of Crematogaster perhaps the least known is Rhachiocrema. The species which belong to this subgenus possess enormously developed epinotal spines. These arise from a relatively narrow thorax but project rearward at a very wide angle so that the distance between their tips exceeds the width of the head or gaster. Up to the present Rhachiocrema has been represented by only two species, wheeleri from the British Solomon Islands and paradoxa from New Guinea. This paper carries the description of a third species from Borneo. References to Rhachiocrema in the literature are scattered and brief. As far as can be determined it has been mentioned only three times since its original description. It is regrettable that two of these references contain serious factual errors. In one case the error has gone uncorrected for more than twenty years. This is not surprising in view of the rarity of the species involved. It has recently been my good fortune to receive a small collection of ants taken in New Guinea by Pvt. Howard Levy, Sn.C., a former City College student. This collection contained four species of Crematogaster, three of which have a bearing on the status of Rhachiocrema. A study of these specimens and a review of the literature both indicate that considerable clarification is needed in the case of this subgenus.

Rhachiocrema was erected as a subgenus by Mann in 1919 (1). Among the ants which he collected in the British Solomon Islands was a remarkable Crematogaster taken in the mountains on the island of Malaita. He described this insect as the species wheeleri and designated it as the type of the new subgenus Rhachiocrema. The only other member of the subgenus cited by Mann was paradoxa, a species from New Guinea which Emery had described in 1894 (2). In view of subsequent events 
it is worth repeating that, as delimited by Mann, the subgenus Rhachiocrema contained only two species, wheeleri and paradoxa. Other features connected with Mann's characterization of Rhachiocrema were by no means so clear. The antennæ were said to be elongate, twelve-jointed and with a distinct two-jointed club. The first and last of these characters would not, of themselves, confer distinction since several species in the subgenus Orthocrema have elongate antennæ with two-jointed clubs. But the number of antennal joints, as given, is unique for Crematogaster. All other known species have eleven-jointed antennæ or, in the case of the subgenus Decacrema, ten- or nine-jointed antennæ. If Rhachiocrema possessed twelve-jointed antennæ its status could be defended without reference to any other structure. Unfortunately this is not the case. Mann overlooked the fact that Emery had described paradoxa as having elevenjointed antennæ, and he miscounted the antennal joints of wheeleri. Both species have eleven-jointed antennæ and Mann's description and figure of wheeleri cannot be relied upon in this particular. When Wheeler published a key to the subgenera of Crematogaster in 1922 (3) he included Rhachiocrema with that group of subgenera which have eleven-jointed antennæ. Although no comment was made concerning the correction it may be presumed that it was based upon an examination of type specimens of wheeleri. To make certain that there is no further confusion in this matter I requested Prof. F. M. Carpenter to examine the type material of wheeleri in the collection of the Museum of Comparative Zoology. Prof. Carpenter has very kindly done so and informs me that specimens have antennæ of eleven joints. While this fact does not necessarily invalidate the status of Rhachiocrema it does place a different value on the other diagnostic characters.

Mann's description of Rhachiocrema appeared after the Myrmicine section of the Genera Insectorum (4) had gone to press. In the preface to that section Emery stated that it was limited to species described up to the end of 1918, but he made an exception in the case of wheeleri. This species was not listed in the usual way but referred to in a footnote on the "paradoxa group," a cluster of four species which Emery included in the subgenus Orthocrema. This footnote contained a peculiar anachronism. Although it correctly cited wheeleri as the type of Rhachiocrema and gave accurate reference to Mann's publi- 
cation it further stated that Mann had elevated the "paradoxa group" into the subgenus Rhachiocrema. As has already been shown Mann made no such proposal, nor could he have done so for the description of Rhachiocrema was published two years before the "paradoxa group" first appeared in print. It is easy to dismiss Emery's mistake as a slip resulting from last minute alterations. It is not so easy to dismiss the consequences of the error. Regardless of what Emery believed and whether he intended to do so or not he originated the concept that all the members of his "paradoxa group" belong to the subgenus Rhachiocrema. There is clear proof that one eminent myrmecologist has accepted this view. When Menozzi published a key to the Malayan and Papuan species of Orthocrema in 1935 (5) he omitted the species in the "paradoxa group." The lack of dissident opinion in the literature indicates that the acceptance has been general. Yet the heterogeneity of the "paradoxa group" is evident from Emery's own work. During the course of his studies on New Guinea ants he described or redescribed each of the four species which he later built into the "paradoxa group." Three of them he figured as well. It is scarcely conceivable that Emery was unaware of their marked dissimilarities. These are even more evident when specimens are available for comparison. In the material sent from New Guinea by Mr. Levy were specimens of paradoxa, polita and irritabilis var. le-guilloui. The remaining species in the group, emeryi, was not represented. The structural contrast between paradoxa and the species irritabilis and polita is striking. For the purpose of this study only two characters will be considered. In paradoxa the antennal scapes project beyond the occipital margin by at least one-quarter of their length and the funiculus is provided with a distinct twojointed club. The huge epinotal spines are more than half as long as the thorax. The base of each spine is stout and cylindrical and, although they arise at the angle between the basal and the declivious faces, their bases are so large that the angle itself is virtually obliterated. There is no infraspinal area in the usual sense of the term because the bases of the two spines involve the entire width of the thorax. In irritabilis the antennal scapes barely reach the occipital border; in polita they exceed it by an amount less than the greatest thickness of the scape. In both these species the funicular club is not distinctly twojointed. The antepenultimate joint is enlarged so that, as Emery 
noted, the club may just as well be considered three-jointed. The epinotal spines of polita are short, their length scarcely exceeding half the distance which separates their bases. The spines of irritabilis are about as long as the distance between their bases but by no stretch of the imagination can they be considered comparable to the colossal spines of paradoxa. As nearly as can be determined from Emery's description and figures of emeryi (6) (originally described by Emery as biroi, a preoccupied name which was later replaced by Forel) this insect is related to irritabilis. The epinotal spines are about the same length in the two species but they turn upward in emeryi and downward in irritabilis. A significant feature of Emery's figure of emeryi is the two-jointed funicular club. The length of the scape cannot be estimated since it was not figured and the description merely states that it is long. But even granting the unlikely supposition that the scape of emeryi is as long as that of paradoxa there is still no possibility of regarding the two insects as closely related.

From the above it seems clear that the only member of the "paradoxa group" which can be assigned to Rhachiocrema is paradoxa itself. The fact is rather too obvious, for the dissimilarity between paradoxa and the remaining species is so marked that it brings up a second problem. Since Emery was fully acquainted with the structure of paradoxa his inclusion of that species in the subgenus Orthocrema raises a question as to the validity of Rhachiocrema. Several of the subgeneric characters of Rhachiocrema are more clearly marked in paradoxa than in wheeleri. Hence if Orthocrema is sufficiently flexible to include paradoxa then wheeleri must also be included and there is no reason for the existence of Rhachiocrema. But it is by no means certain that Emery's treatment of Orthocrema can be justified. The form which Emery gave to his emended version of Orthocrema differed substantially from the original concept of the subgenus which Santschi presented in 1918 (7). Emery combined with Orthocrema the species which Santschi had placed in Neocrema as well as some of the species which Forel had allotted to Physocrema. Emery's reason for this arrangement is interesting and his statement on the matter is given in translation below:

"This subgenus (i.e., Orthocrema) represents, in my opinion, the primitive stock, or at least that which comes nearest to the 
primitive forms in the genus. Mr. Santschi in his recent study on the subgenera of Crematogaster has excluded from it certain species which show a furrow or a more or less marked impression on the postpetiole, on which he founds his subgenus Neocrema. This division which comprises neotropical and malagasian species does not seem homogeneous to me; this is why I have fused it with Orthocrema."

If Neocrema is heterogeneous neither it nor Orthocrema would become more homogeneous when fused. It is unlikely, therefore, that Emery's arrangement of Orthocrema was designed to secure structural uniformity. On the contrary he seems to have deliberately constructed a heterogeneous assemblage for the sake of having all the species which he considered primitive in the same subgenus. However desirable this may be from a phyletic standpoint it is not sound taxonomy to found a group on inconstant characters, which was what Emery did. $\mathrm{He}$ apparently regarded as primitive the rectangular petiole and the entire, globose postpetiole which many of the species in Orthocrema possess. But neither of these features holds for all the species which Emery included in Orthocrema. In the Australian species frivola the postpetiole is as clearly bilobed as in any species of Acrocœlia and the petiole is not markedly rectangular. The shape of the petiole of paradoxa is certainly very far from rectangular. Yet both these extreme conditions can be reached through species in which the conditions are intermediate so that from a phyletic viewpoint the assemblage can be defended. I believe that the phyletic gain which accrues to Emery's arrangement is more than offset by the taxonomic disabilities which it entails. In the form which Emery gave it the subgenus Orthocrema has to be characterized along such generous lines that no satisfactory delimitation of the group is possible. The recognition of Neocrema and Rhachiocrema as valid subgenera relieves Orthocrema of its most incongruous species and permits a much better demarkation of all three subgenera. That the three subgenera tend to intergrade is not a matter for concern for other subgenera of Crematogaster also possess integrading species.

I propose to treat Rhachiocrema as a valid subgenus even though the features which separate it are not as distinct as was originally supposed. Reference has already been made to the fact that antennal structure cannot be used as a basis for sepa- 
ration. The same is true of the pedunculate petiole, for the new species described in this paper has a petiole that is closely similar to that of several species in the subgenus Orthocrema. The one remaining separatory character is the structure of the epinotal spines and, since spine length is such a notoriously variable characteristic, one hesitates to place much value on such a character. In Rhachiocrema, however, the spines show certain features that appear to exclude the possibility of confusion with long-spined species in other subgenera. In addition to their extreme length the spines of Rhachiocrema are not evenly tapered from base to tip. The taper of the thickened basal half of each spine differs from that of the thinner apical half. This break occurs suddenly at a point near the middle of the spine so that when the spine is viewed from the correct angle the two parts can be clearly distinguished. In other species of Crematogaster having long epinotal spines, as for example in the South American species acuta, the spines are evenly tapered from base to tip.

\section{Key to the species of Rhachiocrema}

1. Anterior peduncle of the petiole fully as long as the node itself, the node rounded above and without posterior angles; epinotal spines reflexed at the tip (New Guinea) ........................... paradoxa Anterior peduncle of the petiole shorter than the node, the node flat above and with distinct posterior angles; epinotal spines straight at the tip $\ldots \ldots 2$

2. Entire insect shining and finely punctate; clypeus with five or six longitudinal ridges; color black (British Solomons) ................ wheeleri Head shining with sparse punctures, sides of the mesonotum and much of the epinotum densely and coarsely punctate and subopaque; clypeus bicarinate; color sordid yellow, the gaster castaneous, (Borneo) ........ macracantha

Crematogaster (Rhachiocrema) macracantha sp. nov.

Worker: Length $3.5 \mathrm{~mm}$.

Length of the head from the anterior edge of the clypeus to the occipital border $0.75 \mathrm{~mm}$. The head is slightly longer than broad with the occipital angles broadly rounded and the middle of the occiput flat. The sides in front of the eyes are almost straight, converging gradually to the level of the antennal insertions but more sharply convergent and more curved from that point to the insertion of the mandibles. Eyes suboval, the lower edge much more flattened than the upper, moderately convex with about 10-11 facets in greatest diameter, the facets coarse. Clypeus moderately projecting with two prominent carinæ. 
There is often a delicate carinula lateral to each carina. The central lobe of the clypeus between the two carinæ is distinctly sulcate. Both the sulcus and the carinæ fail to extend entirely across the clypeus so that the posterior part of the clypeus forms an evenly convex bulge between the frontal lobes. The latter are narrow in front, scarcely covering the insertions of the antennæ, but broad and poorly defined behind so that the frontal area is not clearly marked. Antennæ eleven-jointed. Antennal scape long, slightly curved and rather thick at the tip. The scape exceeds the occipital margin by one-quarter of its length. Funicular joints all longer than broad, the first joint as long as the following three together, the last two joints forming a distinct club. Mandibles rather narrow and bearing four teeth, the two outer teeth longer than the inner two.

Overall length of the thorax including the neck $1 \mathrm{~mm}$. Promesonotum seen from above pear-shaped, the promesonotal suture absent. The sides of the thorax at the mesoëpinotal suture are strongly constricted above but less so on the lower portions of the meso- and metapleuræ. Epinotum diamondshaped, about as wide as the pronotum with much of its upper face built into the expanded bases of the spines. The spines long, straight and widely divergent; the basal half of each spine stout, the apical half much thinner. The distance between their tips is $1.4 \mathrm{~mm}$. Seen in profile the promesonotum is not strongly convex. In some specimens it descends through an even curve to the shallow mesoëpinotal suture. In others there is a short, steep posterior face which breaks the even outline of the promesonotum. Basal face of the epinotum virtually flat between the base of the spines and the mesoëpinotal suture. Declivious face largely involved with the base of the spines, the portion below the spines much shorter than the basal face. Anterior peduncle of the petiole distinct but only about one-quarter as long as the node, the latter somewhat longer than broad, broader behind than in front, with the sides feebly convex and narrowing to the shoulders which join the anterior peduncle. The posterior face of the node is straight and transverse, with a distinct angle where it joins the side. Posterior peduncle of the petiole almost as wide as the node itself and not quite as long as the anterior peduncle. Postpetiole seen from above transversely oval with distinct anterior and posterior peduncles. Seen in profile the petiole is wedge-shaped with a very feebly sinuate 
lower surface and a small but distinct tooth under the anterior peduncle. The angles at the posterior face of the node stand out clearly above the posterior peduncle. Postpetiole in profile rounded above, the anterior peduncle sharply set off from the convex anterior face, the posterior peduncle forming an even concavity with the posterior face, the ventral surface flat with a constriction at the anterior peduncle. Gaster triangular, the anterior segment strongly rounded. Sting long.

Sculpture and pilosity: head smooth and shining with a few small, scattered punctures bearing long, rather coarse, erect yellow hairs. Mandibles feebly striate and with sparse, fine, short, subappressed hairs. Prothorax for the most part shining, the neck and the humeral angles coarsely punctato-striate and dull. A few coarse, erect hairs occur on the dorsum of the pronotum. Mesonotum, most of the epinotum and the sides of the petiole densely punctate, feebly shining to dull. Dorsum of the mesonotum and the anterior portion of the basal face of the epinotum with several longitudinal striæ in addition to the punctures. The punctures also occur on the basal half of the epinotal spines but are more feeble there than elsewhere. Declivious face of the epinotum, upper face of the petiole and most of the postpetiole smooth and shining. Epinotum without erect hairs, petiole and postpetiole each with two or more erect hairs. Gaster very delicately coriaceous, the sculpture not heavy enough to dull the shining surface. All gastric segments with moderately numerous erect, yellow hairs. Antennal scapes densely clothed with appressed hairs. Those on the funiculi equally numerous but not so closely appressed; the hairs on the funicular clubs very short, fine and erect. Hairs on the legs rather sparse, fine and closely appressed except for one or two long, erect hairs near the base of each femur.

Color: head, thorax and appendages sordid yellow, the gaster castaneous.

Type locality: Mt. Penrissen, Sarawak, Borneo.

Described from a series of thirty workers taken by E. Mjoberg and given to me many years ago by Dr. W. M. Wheeler.

\section{Literature Cited}

1. Mann, W. M. Bull. Mus. Comp. Zool. Harvard, Vol. LXIII, No. 7, p. 318, 1919.

2. Emery, Carlo. Ann. Soc. Ent. France, Vol. 63, p. 72, 1894.

3. Wheeler, W. M. Bull. Amer. Mus. Nat. Hist., Vol. XLV, p. 661-662, 1922. 
4. Emery, Carlo. In Wytsman Genera Insectorum, Fasc. 174A, p. 130 et seq., 1921.

5. Menozzi, Carlo. Konowia, Band XIV, Heft 1, p. 112-114, 1935.

6. Emery, Carlo. Termeszetrajzi Füzetek, Vol. 23, p. 332, 1900.

7. Santschi, F. Bull. Soc. Ent. France, p. 182-184, 1918.

\section{Explanation of Plate 12}

Figs. 1 and 2. Crematogaster (Rhachiocrema) paradoxa Emery. Fig. 3. Cr. (Rhachiocrema) wheeleri Mann after Mann. Figs. 4 and 5. Cr. (Rhachiocrema) macracantha $\mathrm{n}$. sp. 


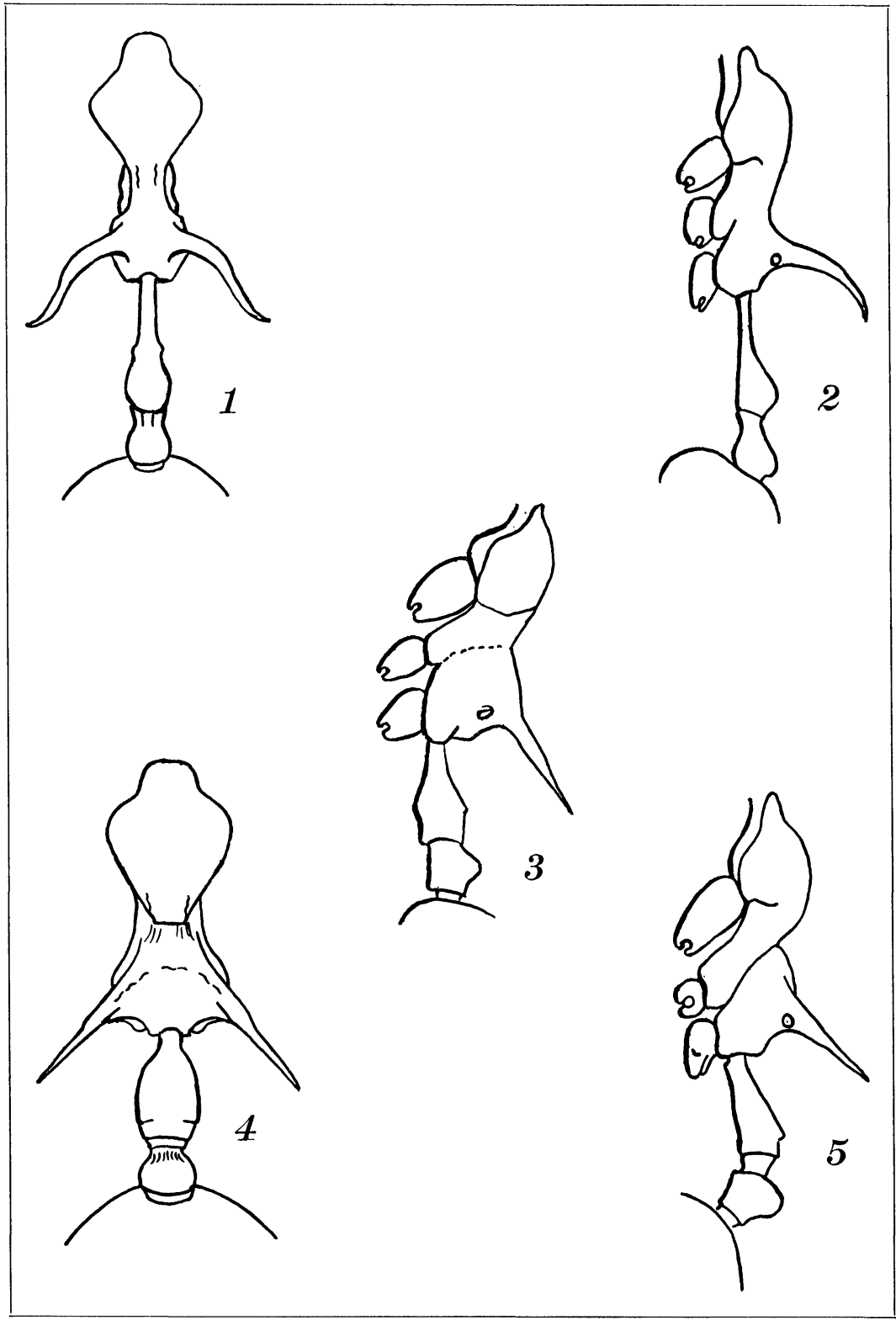



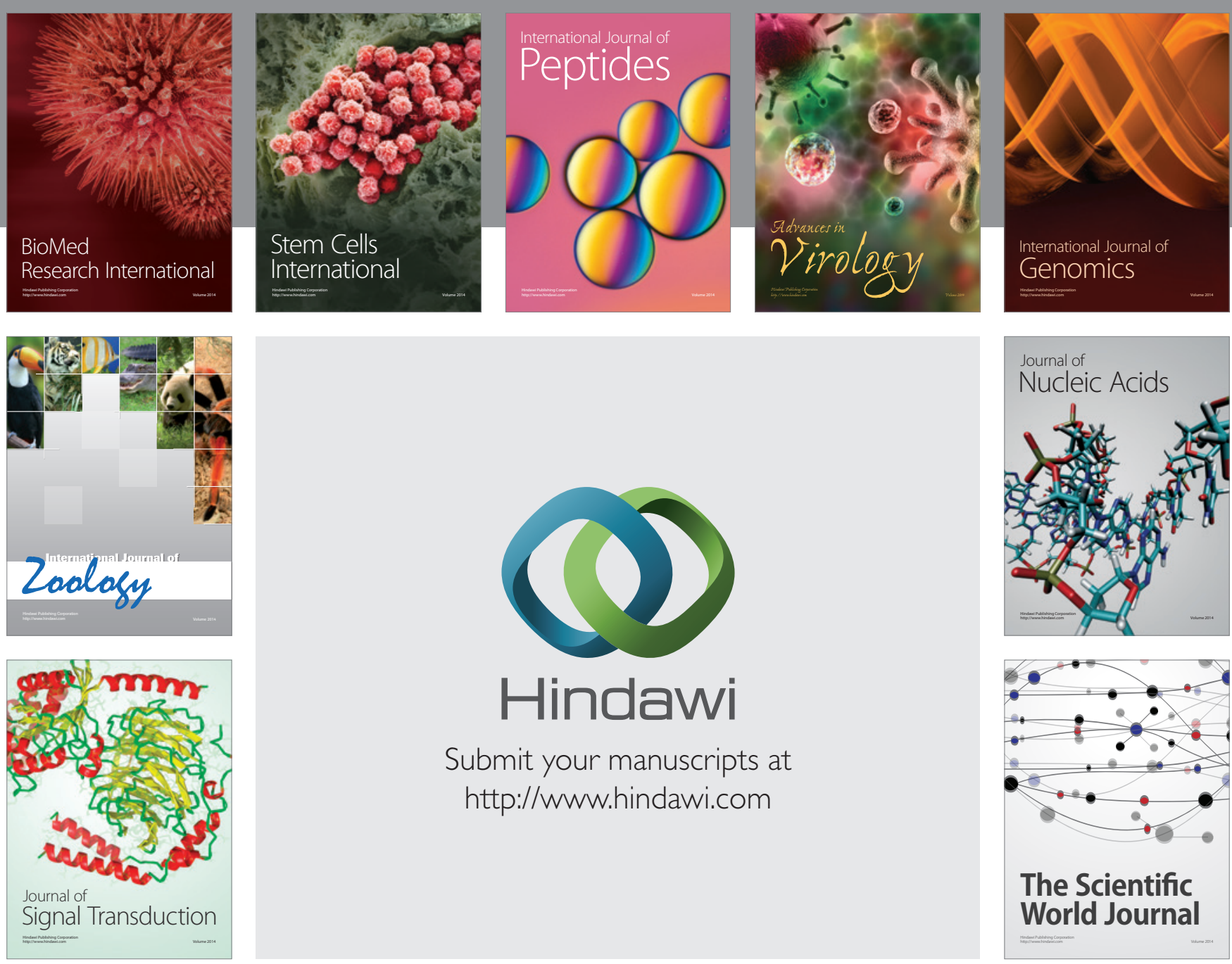

Submit your manuscripts at

http://www.hindawi.com
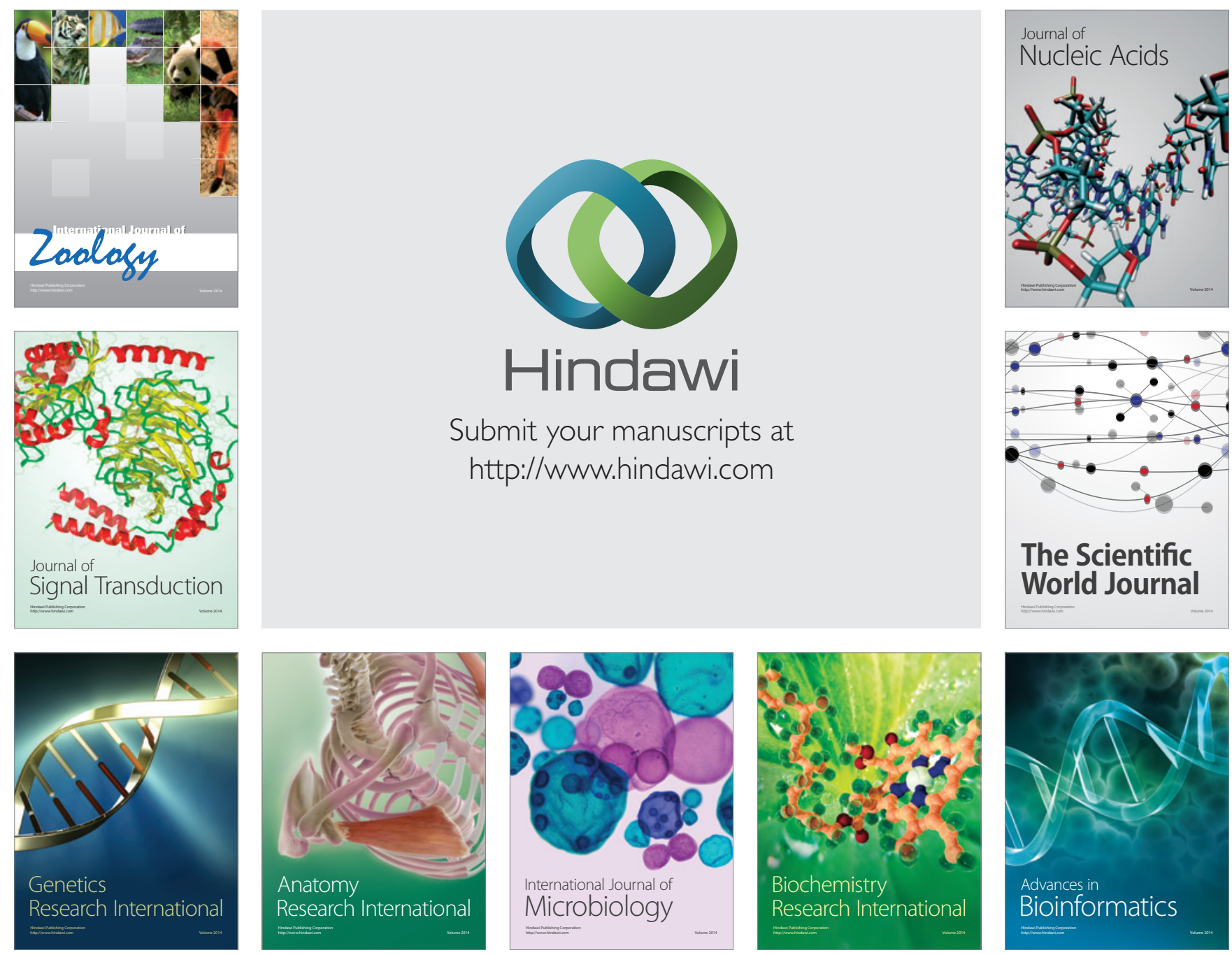

The Scientific World Journal
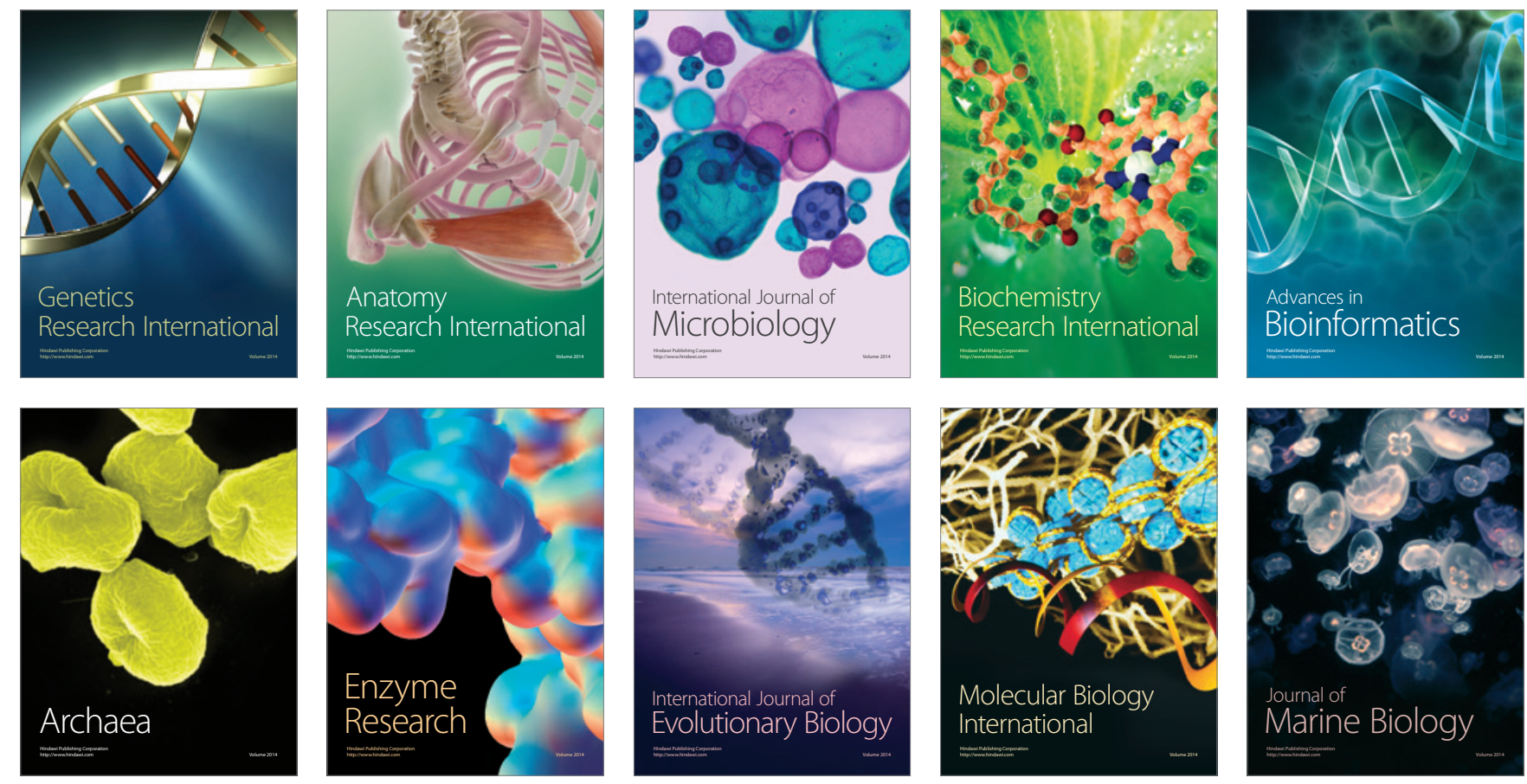